\title{
Optimization of Genetic Algorithm in Courses Scheduling
}

\author{
Andi Andi ${ }^{1}$ and Dewi Nasien ${ }^{2}$ \\ Department of Information Technology, Faculty of Computer Science, Institut Bisnis dan Teknologi Pelita \\ Indonesia ${ }^{1,2}$ \\ andi.m2@student.pelitaindonesia.ac.id ${ }^{1}$, dewinasien@lecturer.pelitaindonesia.ac.id ${ }^{2}$
}

\begin{tabular}{l}
\hline \hline Article Info \\
\hline Article history: \\
Received Oct 21, 2021 \\
Revised Nov 26, 2021 \\
Accepted Jan 26, 2021 \\
\hline
\end{tabular}

\section{Keyword:}

Class scheduling

Genetic Algorithm

Optimization

\begin{abstract}
Scheduling courses is an intricate and pivotal part of a university as it impacts the teaching and learning process. The problem frequently occurs is the struggle of placing schedules which is manual, takes a long time, and inaccurate. This paper explores the process and how effective the genetic algorithm method is in solving scheduling problems in lecture environment. The selection of genetic algorithms owes to it produces an optimal scheduling solution. To build a scheduling optimization system, it is essential to collect room data, lecturers, courses, days and hours of teaching. The data collection comes from field studies by observations and interviews. Literature studies are also needed to acquire the basic course scheduling, optimization, genetic algorithms, PHP, MySQL, Bootstrap, and Visual Studio Code. The test outcomes attained the preeminent one with the highest fitness value in the number of generations, populations, the crossover combination and mutation rates. The final result showed that the first chromosome is the finest chromosome produces scheduling with the highest fitness value. The outcomes of the whole algorithm process are consistent with the original predicted data, and the same lecturer is not scheduled to teach more than once at the same time. It is expected that the application of the genetic algorithm method optimizes course scheduling with great outcome.
\end{abstract}

(C) This work is licensed under a Creative Commons AttributionShareAlike 4.0 International License.

\section{Corresponding Author:}

Dewi Nasien,

Department of Information Technology, Faculty of Computer Science, Institut Bisnis dan Teknologi Pelita Indonesia

Jl. Jend. Ahmad Yani, Pekanbaru, Indonesia

Email: dewinasien@lecturer.pelitaindonesia.ac.id

\section{INTRODUCTION}

Before the existence of computers, managing activities felt time-consuming. However, the development of technology and computer science today is rapidly transforming everyday human life, i.e., every job might be realized more efficiently and effectively. The development of information technology at this time has been able to aid human activities [1]. It accelerates all activities might be conducted in a shorter time, particularly in data processing systems to become precise and accurate information [2].

Currently, there are various efforts to improve the quality of education for its development in Indonesia. One of them is improving the teaching and learning process by dividing the class evenly [3]. Every new semester, a course schedule will be arranged manually, which requires accuracy in 
compiling the schedule and somehow causes a clash between rooms. Poorly designed timetables are not only inconvenient, but outsome in significant losses in terms of time, effort and money [4]. For instance, the considerations reached to develop a schedule need to pay attention to several elements, such as lecturers, students, rooms and schedule [5]. The utilization of technology in higher education is limited to assisting the administrative process and teaching and learning and arranging class schedules or often called scheduling [6].

The schedule arrangements and rooms repeatedly do not meet expectations. The arrangement at educational institutions run conventionally without involving a computational process might be ineffective if numerous parameters and limitations are employed [7] lecturers and students often experience class clashing problems. The officers sometimes assist and discover a room for learning as well. The lecturer takes an empty room without the officer concern, so they who teaches in the room get baffled. Scheduling is the process, method, schedule creation or inclusion in the timetable. Its problems are concerned with allocating resources to specific functions. The purpose of scheduling is to optimize one or more objectives. The activity of implementing a lecturer's teaching schedule on campus is complicated.

To overcome these problems, it is necessary to generate an optimal lecture scheduling through a Genetic Algorithm approach to acquire an ideal solution value to a problem with many possible ways [5, 8]. A genetic algorithm is one of the techniques applied in the optimization process. Genetic algorithms begin with the initial population formation process, selection, crossing, and mutation. As happens in processes that occur in nature, the selection process of crosses and mutations is used in the hope that the offspring resulting from the process have better quality than their parents [9]. Optimizing class promotion and division will simplify and shorten the class division process if it is done automatically by a computer [10]. Genetic algorithms' attractiveness lies in their simplicity and ability to find excellent and fast solutions to complex problems [11]. It is used due to its efficient, parallel, and global search characteristics [12].

The previous research [2] executed genetic algorithms with title "Perancangan Sistem Informasi Penjadwalan Mengajar Menggunakan Metode Algoritma Genetika (Studi Kasus: SMK Satria Jakarta)". The problems found in previous research are similar to the study: making a schedule done manually and takes a long time. Researchers implemented this genetic algorithm to look for possible solutions to earn the optimal solution to the problem.

The next study was conducted by [13] with the title "Sistem Penjadwalan mata Pelajaran di SMA Muhammadiyah 1 Kota Magelang dengan Algoritma Genetika". This study indicates that the scheduling application has been designed has a positive impact on scheduling in general. With this genetic algorithm, the schedule becomes more organized and better than the previous schedule preparation by a manual system.

In [14] findings with a study entitled "Konsep Algoritma Genetic Biner Untuk Optimasi Perencanaan Jadwal Kegiatan Perkuliahan", the assistance of binary genetic algorithms in a preparation of lecture schedule can be utilized. By being implemented with one of the programming languages in optimization science, such as Mathlab or Labview, a program can find scheduling solutions at an exact time, either by lecturers, classes, or rooms, related to a course in a brief time.

The subsequent research employing genetic algorithms was carried out by [15], who raised the title " Penerapan Algoritma Genetika dalam Optimasi Penjadwalan Proyek." The problems found in previous research are the same as the researchers: creating a schedule that is done manually and takes a long time. Researchers use this genetic algorithm due to the genetic algorithm is looking for possible solutions to acquire the optimal solution to the problem.

Lastly, [16] conducted research with topic "Sistem Pejadwalan Kuliah Meggunakan Metode Algoritma Genetika pada Program Magister Fakultas Ekonomi dan Bisnis". Optimization of the lecture scheduling system has been developed by the Genetic Algorithm in the FEB Masters Program. As maintained by the respondents and the implementation of the application program, it is concluded that an average of $93 \%$ of respondents stated that it was constructive and affluent to apply as a tool in assisting the scheduling optimization lecturer process to minimize schedule conflicts in lectures. 
Through an algorithm method, a unified schedule and room are understood as individuals with innumerable genes. The gene is the embodiment of the lecturer arrangement code settled in an array. Copius individuals with random genes will be generated in initial process. Subsequently, the quality of the schedule might be weighted as a fitness value will be an individual quality number. The more the individual is of decent quality, the greater the fitness value. A selection process with a high probability is performed, with a high fitness as well. A crossover process is carried out by cutting individuals and pairing other individuals. Moreover, the next step is to mutate genes. This individual will experience iteration continuously for obtaining individual or receiving the optimal schedule and room in keeping with the expectations.

In accordance with the previous elaboration, there are several research questions is need to be adjust: 1) How to apply the genetic algorithm method in scheduling and room optimization in a campus environment? 2) how is the process of scheduling with the genetic algorithm method? 3) how effective is the genetic algorithm method in solving scheduling and room problems? Therefore, researchers are interested in finding solutions in compiling a teaching schedule can be done quickly and efficiently. Researchers conducted this research with focus on one of the study programs in Pekanbaru's private university. Creating a schedule and room planning system is assumed to facilitate and speed up room planning. The schedule creation process obtains optimal and effective solutions to minimize clashes between rooms and schedules with the intention that not the entire schedule reshuffle has been arranged.

\section{RESEARCH METHOD}

This study uses a qualitative method by applying several steps as follows:

a. Formulation of the problem

At this stage, the researchers conducted a survey to lecturers to clarify the problem, it would be easier to perform further discussions.

b. Data collection

The variables in designing a class scheduling optimization system include lecturer data, room data, course data, day data, and teaching hours data. The following data collection is carried out in two steps as follows:

1) Field studies were conducted in two ways, namely observation and interviews. Researchers made observations to attain subject data and lecturers' data in the Informatics Engineering undergraduate study program. Interviews were conducted to find out problems and information on teaching hours data and lecturer limit data.

2) Literature study aims to determine the basic concepts support this research. The literature reviewed in this study relates to course scheduling, optimization, genetic algorithms, PHP, MySQL, bootstrap and Visual Studio Code.

c. Genetic Algorithm Design

A Genetic Algorithm (GA) is a search/heuristic algorithm elicited from natural selection and biological evolution mechanisms [17]. The Genetic Algorithm design process in the Class Scheduling Optimization System consists of input data processing, course data coding, chromosome formation from the population, fitness evaluation, selection process, crossover, mutation process and completion conditions.

The series of genetic algorithm processes is described in Figure 1:

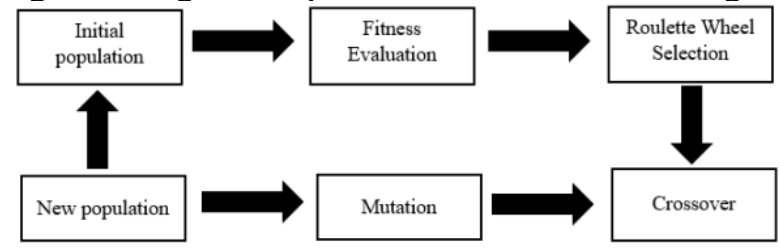

Figure 1. Genetic Algorithm Process 
d. Evaluating the results from the method

The evaluation process is essential to determine the feasibility of the output outcome, and it is by the variables and algorithm processes.

\section{RESULTS AND ANALYSIS}

Utilizing scheduling system design, the chromosomes are along these lines: 1) Course Code (MK), 2) Lecturer Code (DS), 3) Room Code (RG), and Lecture Hour Code (JK). The new chromosome arrangement is derived from the four chromosomes: $\langle\mathrm{MK}, \mathrm{D}, \mathrm{R}, \mathrm{JK}\rangle$. The length of a chromosome is a combination of genes pertaining to the total number of courses and classes offered in the active semester. One gene covers time and hour information for one subject and class. As proof, for the initialization of the chromosome's formation, as seen in Table 1, the distribution of lesson hours is for courses for odd semesters and in Table 2 for schedule hours.

Table 1. Distribution of Subjects

\begin{tabular}{ccccccc}
\hline No & $\begin{array}{c}\text { Subject } \\
\text { Name ID }\end{array}$ & Subject & $\begin{array}{c}\text { Lecturer } \\
\text { ID }\end{array}$ & $\begin{array}{c}\text { Lecturer's } \\
\text { Name }\end{array}$ & $\begin{array}{c}\text { Room } \\
\text { ID }\end{array}$ & Room Name \\
\hline 1 & MK01 & Pancasila & DS01 & A & R01 & Teknik Informatika \\
2 & MK02 & Aljabar Linear & DS02 & B & R02 & Teknik Informatika \\
3 & MK03 & Statistika & DS03 & C & R03 & Teknik Informatika \\
4 & MK04 & Kewarganegaraan & DS01 & A & R04 & Teknik Informatika \\
\hline
\end{tabular}

Table 2. Schedule Hours

\begin{tabular}{ccc}
\hline Time Index & Day & Time \\
\hline T01 & Monday & $17.00-18.30$ \\
T02 & Tuesday & $19.00-20.30$ \\
T03 & Wednesday & $17.00-18.30$ \\
T04 & Thursday & $19.00-20.30$ \\
\hline
\end{tabular}

It is assumed there are four chromosomes in one population and the number of courses available, and each chromosome has four genes. In preparing the initial population, it is taken from Table 1 and Table 2. The two tables obtained Table 3 with the initial population structure where MK01 represents the code for course one, DS01 for lecturer one, RG01 for room one, and JK for room one lecture hours. Determination of the code sequence of each gene is completed randomly. The example is the sum of all courses and hours offered.

Table 3. Initial Population Composition

\begin{tabular}{llll}
\hline R01,DS01,MK01,T01 & R01,DS02,MK04,T04 & R01,DS02,MK03,T02 & R01,DS02,MK02,T03 \\
R01,DS03,MK01,T04 & R01,DS03,MK04,T02 & R01,DS02,MK02,T01 & R01,DS03,MK03,T03 \\
R01,DS01,MK02,T03 & $\underline{\text { R01,DS02,MK02,T01 }}$ & R01,DS02,MK03,T04 & $\underline{\text { R01,DS01,MK04,T01 }}$ \\
R01,DS01,MK01,T02 & R01,DS02,MK03,T03 & R01,DS02,MK04,T04 & $\underline{\text { R01,DS01,MK01,T02 }}$ \\
\hline
\end{tabular}

As presented in Table 3, the code sequence of each gene represents the course code, lecturer code, class code, and time code.

\subsection{Fitness Function}

The selection stage is composed to established the best prominent individual with a fitness function. A fitness function returns the highest value for the best individual and is sorted by value or called selection [18]. This function indicates the optimal solution since the only chromosome with the highest fitness value will persist. In this case, each violation is given a value of 1 , so there is no infinite fitness value, and the violation's total value will be added to a value of 1 . Some limitations prioritized in preparing this schedule are that lecturers cannot be planned to teach more than once at the same time, and neither the class can.

a) Lecturers should not be scheduled to teach more than once at the same time. 
b) One class may not be scheduled more than once simultaneously.

From the composition of the initial population in Table 3, it is evident there is no superior violation on chromosomes $1 \& 2$. On chromosomes $3 \& 4$, there is an outstanding violation where on chromosome 3 there are two genes, namely 2 and 4, which have similarities in class (R01) and clock (T01), on the 4th chromosome, there are also violations, namely in genes 1 and 4 which have the similar class (R01), lecturer (DS01), subject (MK01) and time (T02). The existing violations will produce the following fitness values:

\section{Fitness Function $=\frac{1}{1+(\text { objective function })}$}

Figure 2. Fitness Function Calculation Formula

Description:

Fitness Function $=$ Fitness Function

Objective Function $=$ Number of Collisions

$$
\begin{aligned}
& \text { Chromosome Fitness } 1=\frac{1}{1+(0+0+0+0)}=1 \\
& \text { Chromosome Fitness } 2=\frac{1}{1+(0+0+0+0)}=1 \\
& \text { Chromosome Fitness } 3=\frac{1}{1+(1+0+0+1)}=0.33 \\
& \text { Chromosome Fitness } 4=\frac{1}{1+(1+1+1+1)}=0.2
\end{aligned}
$$

\subsection{Selection}

At this stage for forming a new population, the method is the Roulette-wheele selection method. In this selection, individuals are selected drew on their fitness values to choose which individuals will undergo the mating process or cross over [19]. Each chromosome occupies a piece of the circle proportionally accordant with its fitness value which is acquired from the calculation of the fitness function contained in Table 3. The first step is to estimate the total fitness value of all chromosomes, as in Table 4.

Table 4. Fitness Value

\begin{tabular}{cc}
\hline Chromosomes & Fitness Value \\
\hline 1 & 1 \\
2 & 1 \\
3 & 0.33 \\
4 & 0.2 \\
\hline Total Fitness Score & $\mathbf{2 . 5 3}$ \\
\hline
\end{tabular}

The second step is to calculate the probability of each chromosome by dividing its fitness value by the total fitness value, as depicted in Table 5.

Table 5. Probability of Fitness Value

\begin{tabular}{cc}
\hline Chromosomes & Probability \\
\hline 1 & $1 / 2.53=0.39$ \\
2 & $1 / 2.53=0.39$ \\
3 & $0.33 / 2.53=0.14$ \\
4 & $0.2 / 2.53=0.08$ \\
\hline
\end{tabular}

The third step is to place each chromosome in the value interval [0-1] as demostrated in Table 6. 
Table 6. Probability Value Interval

\begin{tabular}{cc}
\hline Chromosomes & Interval Nilai \\
\hline 1 & $0-0.39$ \\
2 & $0.40-0.78$ \\
3 & $0.79-0.92$ \\
4 & $0.93-1$ \\
\hline
\end{tabular}

Due to the selection, a random number is generated between [0-1] to regulate the new population composition. To illustrate, the generated number is $[0,2 ; 0.8 ; 0.5 ; 0.95]$. From the randomly generated values, it is obvious that the chromosome with a value of 0.2 is the first chromosome, with an interval of 0-0.39. First Chromosome does not undergo selection, as a result, the chromosome with a value of 0.8 is the third chromosome with an interval of $0,79-0.92$. This chromosome undergoes second pick, and automatically the second chromosome also sustains selection by filling in the third chromosome position. The chromosome with a value of 0.95 is the fourth chromosome with a $0.93-1$ value interval. Thus, it does not endure selection due to the random value generated corresponds to the interval value on the chromosome. Thus, the chromosomal arrangement of the new population is the selection process outcome as presented in Table 7.

Table 7. Chromosomal Arrangement of the New Population

\begin{tabular}{ccccc}
\hline Chromosom & R01,DS01,MK01,T & R01,DS02,MK04,T & R01,DS02,MK03,T & R01,DS02,MK02,T \\
es 1 & 01 & 04 & 02 & 03 \\
Chromosom & R01,DS02,MK02,T & $\underline{\text { R01,DS02,MK02,T }}$ & R01,DS02,MK03,T & $\underline{\text { R01,DS01,MK04,T }}$ \\
es 2 & 03 & $\underline{01}$ & 04 & $\underline{01}$ \\
Chromosom & R01,DS01,MK01,T & R01,DS01,MK04,T & R01,DS02,MK02,T & R01,DS03,MK03,T \\
es 3 & 04 & 02 & 01 & 03 \\
Chromosom & $\underline{\text { R01,DS01,MK01,T }}$ & R01,DS02,MK03,T & R01,DS02,MK04,T & $\underline{\text { R01,DS01,MK01,T }}$ \\
es 4 & $\underline{02}$ & 03 & 04 & $\underline{02}$ \\
\hline
\end{tabular}

\subsection{Crossover}

Crossover is employed to cut chromosomes randomly and merges the initial part of the first main chromosome with the second part of the second main chromosome. Mating genes of the same type do crossover by randomizing the lines. Crossover is done if there is a random number value generated by a chromosome that is less than the probability value, it has been set where the random number value is, in particular, $[0,2 ; 0.8 ; 0.5 ; 0.95]$ and the probability value is generally set to a minimum of 0.5 .

The random number generated to determine the position of the intersection point is $[1-\mathrm{N}]$, where $\mathrm{N}$ is the number of genes in one chromosome. The random number values generated in Table 7 undergo crossover are chromosomes 1 and 3. They have a value less than the predetermined probability value, where chromosomes 1 and 3 are worth 0.2 and 0.5 . Derived from the cutting position, the second gene position is selected. Hence, the crossover process is as displayed in Table 8.

Table 8. Crossover Process and Chromosome Fitness

\begin{tabular}{lllll}
\hline Chromosom & R01,DS01,MK01,T & R01,DS02,MK04,T & R01,DS02,MK03,T & R01,DS02,MK02,T \\
es 1 & 01 & 04 & 02 & 03 \\
Chromosom & R01,DS01,MK01,T & R01,DS01,MK04,T & R01,DS02,MK02,T & R01,DS03,MK03,T \\
es 3 & 04 & 02 & 01 & 03 \\
\hline
\end{tabular}


The result from the crossover of chromosome 1 and chromosome 3 are as follows:

\begin{tabular}{|c|c|c|c|c|}
\hline $\begin{array}{l}\text { Chromosom } \\
\text { es } 1 \\
\text { Chromosom } \\
\text { es } 3\end{array}$ & $\begin{array}{l}\frac{\mathbf{R 0 1}}{\mathbf{0 1}}, \mathrm{DS} 01, \mathrm{MK} 01, \underline{\mathbf{T}} \\
\frac{\mathbf{R} 01}{\mathbf{0 4}}, \mathrm{DS} 01, \mathrm{MK} 01, \underline{\mathbf{T}}\end{array}$ & $\begin{array}{l}\mathrm{R} 01, \mathrm{DS} 01, \mathrm{MK} 04, \mathrm{~T} \\
02 \\
\underline{\mathbf{R 0 1}}, \mathrm{DS} 02, \mathrm{MK} 04, \mathbf{T}\end{array}$ & $\begin{array}{l}\underline{\mathbf{R 0 1}}, \mathrm{DS} 02, \mathrm{MK} 02, \underline{\mathbf{T}} \\
\underline{\mathrm{R} 01} \\
02\end{array}$ & $\begin{array}{l}\text { R01,DS03,MK03,T } \\
03 \\
\text { R01,DS02,MK02,T } \\
03\end{array}$ \\
\hline
\end{tabular}

Fitness of chromosome 1 after crossing over.

Chromosome Fitness $1=\frac{1}{1+(1+0+0+1)}=0.33$

Fitness Chromosome 3 after crossing over.

Chromosome Fitness $3=\frac{1}{1+(1+0+0+1)}=0.33$

\subsection{Mutation}

After the crossover process, the next step is the mutation process. Mutation is a genetic algorithm operator that aims to form worthy individuals or have above average quality. In addition, mutations are used to restore genetic material damage due to the crossover process [20]. This change can build the duplication solution with a lower or higher fitness value than the leading solution.

For all existing genes, if the produced random number is less than the mutation probability, some gene information will be changed with the value coding method to produce better fitness values and improve the courses placement that are not as expected. To secure the gene's position to be mutated, it is necessary to calculate the total number of genes in a population using Formula 3.1.

Total genes $=$ number of genes in one chromosome $\mathrm{x}$ number of chromosomes present (3.1).

In comformity with the examples, the total genes are $4 \times 4=16$. The mutation probability is set at 0.1 and it is presumed that mutations will occur, namely $0.1 \times 16=1.6=2$. Two genes will experience mutations. Next, iterate over the total number of genes $(0-16)$ and generate random numbers for each iteration between (0-1). It is presumed that the genes become numbers under the mutation probability are the second and third genes on chromosome 1 . The information in these genes will be transformed in lecture hours, thus, the results on the chromosomes are gained, as shown in Table 9.

Chromosomes before mutation are R01,DS01,MK01,T01; R01,DS01,MK04,T02; R01,DS02,MK02,T01; R01,DS03,MK03,T03, while after the mutation, R01,DS01,MK01,T01; R01,DS01,MK04,T02; R01,DS02,MK02,T04; R01,DS03,MK03,T03. From the mutation process, it will produce a new chromosomal arrangement as seen in Table 9:

Table 9. New Chromosomal Arrangement

\begin{tabular}{lllll}
\hline Chromosomes 1 & R01,DS01,MK01,T01 & R01,DS01,MK04,T02 & R01,DS02,MK02,T04 & R01,DS03,MK03,T03 \\
Chromosomes 2 & R01,DS02,MK02,T03 & $\underline{\text { R01,DS02,MK02,T01 }}$ & R01,DS02,MK03,T04 & $\underline{\text { R01,DS01,MK04,T01 }}$ \\
Chromosomes 3 & R01,DS01,MK02,T03 & $\underline{\text { R01,DS02,MK02,T01 }}$ & R01,DS02,MK03,T04 & $\underline{\text { R01,DS01,MK04,T01 }}$ \\
Chromosomes 4 & $\underline{\text { R01,DS01,MK01,T02 }}$ & R01,DS02,MK03,T03 & R01,DS02,MK04,T04 & $\underline{\text { R01,DS01,MK01,T02 }}$ \\
\hline
\end{tabular}

The fitness value of each chromosome from the results of the mutation process above is:

Fitness of chromosome 1 after mutation

Chromosome Fitness $1=\frac{1}{1+(0+0+0+0)}=1$

Fitness Chromosome 2 after mutation

Chromosome Fitness $2=\frac{1}{1+(1+0+0+1)}=0.33$

Fitness Chromosome 3 after mutation

Chromosome Fitness $3=\frac{1}{1+(1+0+0+1)}=0.33$ 
Fitness Chromosome 4 after mutation

Chromosome Fitness $1=\frac{1}{1+(1+1+1+1)}=0.2$

From fitness values results in Table 9, the first chromosome is picked as the chromosome that has the best fitness value as there are no defined violations and is the required solution. While the other chromosomes still have clashes between classes and schedule hours. The results of the entire algorithm process are following the original expected data, the same lecturer is not planned to teach more than once simultaneously. One class is not scheduled more than once at a time. The final results of the process can be seen in Table 10.

Chromosome 1 = R01, DS01, MK01, T01 | R01, DS02, MK04, T02 | R01,DS02,MK02,T04 |

R01, DS03, MK03, T03

Table 10. Process Results

\begin{tabular}{cccccccc}
\hline Subject ID & Subject Name ID & $\begin{array}{c}\text { Lecture } \\
\text { ID }\end{array}$ & $\begin{array}{c}\text { Lecturer' } \\
\text { s Name }\end{array}$ & $\begin{array}{c}\text { Room } \\
\text { ID }\end{array}$ & Room Name & $\begin{array}{c}\text { Time } \\
\text { ID }\end{array}$ & Time \\
\hline MK01 & Pancasila & DS01 & A & K01 & Teknik Informatika & T01 & $17.00-18.30$ \\
MK04 & Kewarganegaraan & DS01 & A & K01 & Teknik Informatika & T02 & $19.00-20.30$ \\
MK02 & Aljabar Linear & DS02 & B & K01 & Teknik Informatika & T04 & $19.00-20.30$ \\
MK03 & Statistika & DS03 & C & K01 & Teknik Informatika & T03 & $17.0-18.30$ \\
\hline
\end{tabular}

\subsection{Implementation of the Generate Lecture Scheduling System Process}

The design of this input output is described in depth in relation to the system being developed, where what will be presented is the design of desired inputs and outputs.

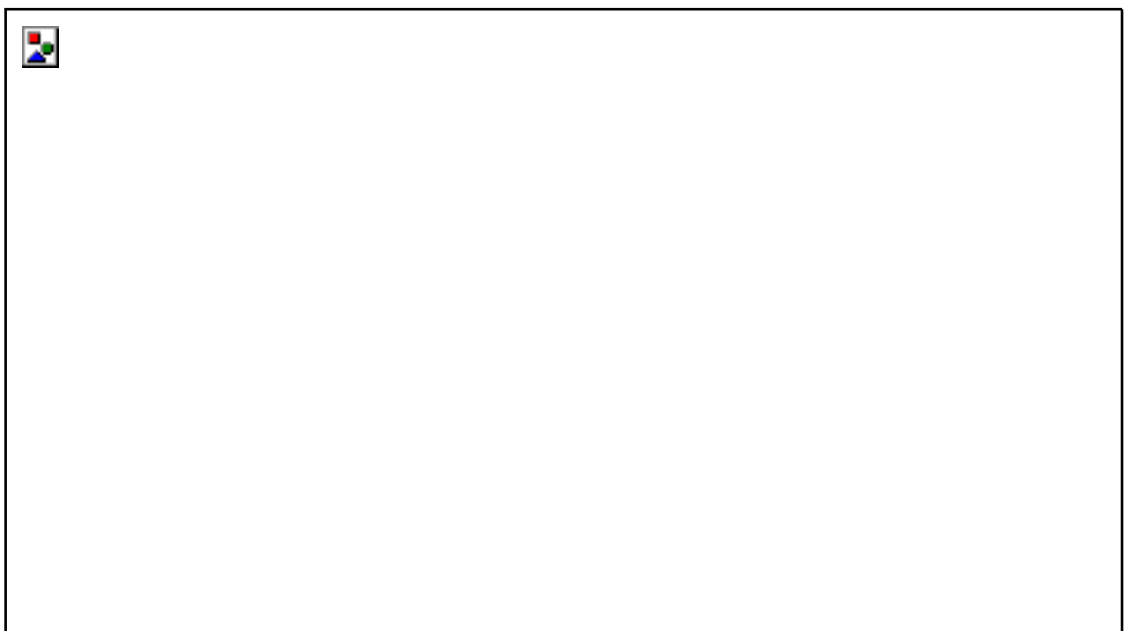

Figure 3. Implementation of the Generate Lecture Scheduling System Process

Figure 3 demonstrates that the generate scheduling process page contains the process view and the calculation of the genetic algorithm method to bring about all the criteria to procure the outcomes provided, thus, there are no more prolonged constraints in the scheduling process, consisting of Subject, Maximum Class, Semester Package, Semester, Study Program, Number of Credits, and Predicted Number of Interests. Only admin can access this page.

\subsection{Implementation of Lecture Scheduling Results}




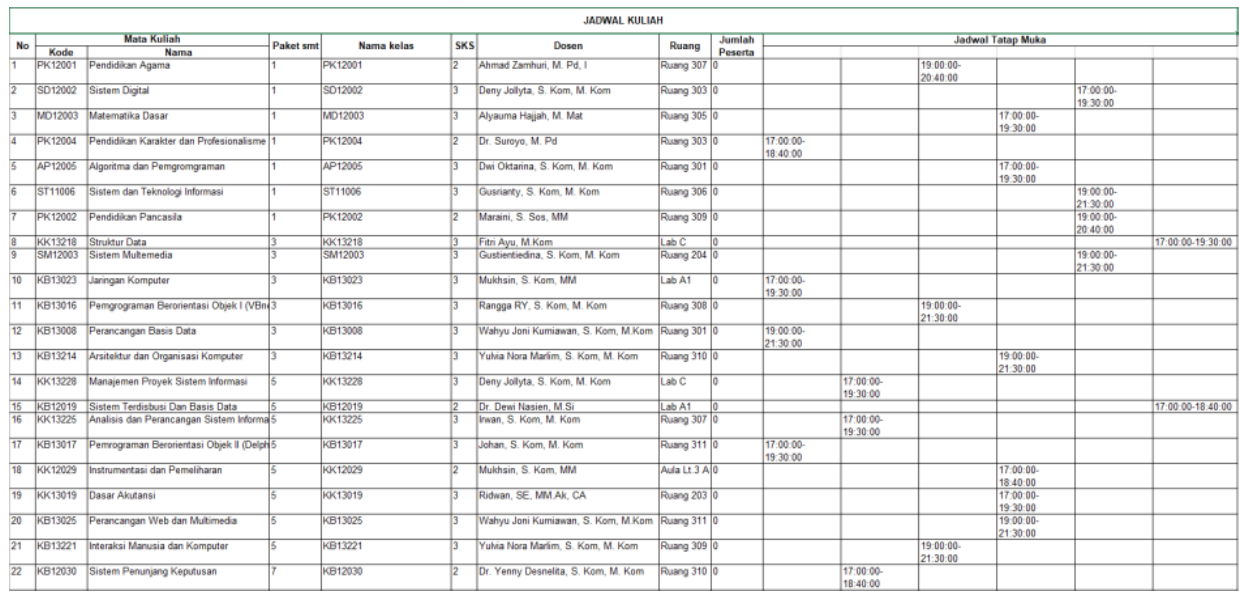

Figure 4. Lecture Scheduling Results

In figure 4 , it exhibits that the scheduling page comprises the mastering of the scheduling outcome from the genetic algorithm generate process. On this page, it is perceived that a fixed schedule has been formed for the lecturer, and there are certainly no issues in a course schedule. Only admins can access this page and have a search feature under needs will be selected.

\section{CONCLUSION}

Based on the fitness values results, the first chromosome is picked as the chromosome that has the best fitness value as there are no defined violations and is the required solution. While the other chromosomes continue to have conflicts with classes and scheduling hours. The outcomes of the whole algorithm process are consistent with the original predicted data, and the same lecturer is not scheduled to teach more than once at the same time.

While the other chromosomes still have clashes between classes and schedule hours. This research proves genetic algorithms can process large amounts of data in just seconds. The results from the course scheduling process using the genetic algorithm acquire a pretty good optimization in scheduling this course. If there is a clash between classes, the data will be reprocessed to procure schedule. It is accepted the application created can be applied by room officers to shorten the time of preparing a schedule.

The result of this study is in line with several previous research related to the genetic algorithm for scheduling process. Research by [11] revealed that the application has a positive impact on scheduling in general. The schedule got more structured and better with this genetic algorithm than with the prior schedule creation using a manual system. In [12] findings with the assistance of binary genetic algorithms in a preparation of lecture schedule which can be utilized. By being implemented with one of the programming languages in optimization science, such as Mathlab or Labview, a program can find scheduling solutions at an exact time, either by lecturers, classes, or rooms, related to a course in a brief time. The last research employing genetic algorithms was carried out by [14] with optimization of the lecture scheduling system has been developed by the Genetic Algorithm in the FEB Masters Program. It is concluded that an average of 93\% of respondents stated that it was constructive and affluent to apply as a tool in assisting the scheduling optimization lecturer process to minimize schedule conflicts in lectures.

Finally, the researchers would like to give some suggestions hoping that this study is helpful for lecturers and students. There are limitations experienced by researchers considering the amount of data and information must be processed and needed to avoid errors in generating the system so deficiencies to be overcome. Future research should therefore concentrate on giving additional features that are easier to fathom and more organized. 


\section{REFERENCES}

[1] N. L. G. P. Suwirmayanti, I. M. Sudarsana, and S. Darmayasa. "Penerapan Algoritma Genetika Untuk Penjadwalan Mata Pelajaran." Journal of Applied Intelligent System, vol. 1, no. 3, pp. 220-233, 2016.

[2] T. R. Ahyana and Y. Jumaryadi. "Perancangan Sistem Informasi Penjadwalan Mengajar Menggunakan Metode Algoritma Genetika (Studi Kasus: Smk Satria Jakarta)”, Ensiklopedia of Journal, vol. 1. no. 2 , 2019.

[3] M. S. Iriana, and D. Suryani, "Optimasi Pengacakan Kenaikan Kelas Di Sma Menggunakan Algoritma Genetika", SENTIA 2018 vol. 10, no. 1, 2018.

[4] E. A. Abdelhalim, and G. A. El Khayat. "A utilization-based genetic algorithm for solving the university timetabling problem (uga)." Alexandria Engineering Journal, vol. 55 no. 2, pp. 1395-1409. 2016.

[5] A. T. Ma'arif, D. P. Pamungkas, and R. Wulanningrum, "Penerapan Metode Algoritma Genetika untuk Optimasi Penjadwalan Mata Kuliah", Prosiding Semnasinotek 2020, 2020.

[6] A. Josi. "Implementasi Algoritma Genetika Pada Aplikasi Penjadwalan Perkuliahan Berbasis Web Dengan Mengadopsi Model Waterfall (Studi Kasus: STMIK Prabumulih)." Jurnal Informatika: Jurnal Pengembangan IT, vol 2, no. 2, pp.77-83, 2017.

[7] L. A. Aditya, and W. M PD. "Implementasi algoritma genetika untuk penjadwalan mata pelajaran pada lms getsmart," Jurnal Mantik Penusa vol. 21. no.1, 2017.

[8] M. S. Al-Ghofany, I. G. S. P. Wijaya, and N. Maududi, "Sistem informasi penjadwalan pembelajaran pada SMAN 5 Mataram", Jurnal Begawe Teknologi Informasi (JBegaTI,) vol. 1. no. 1, 2020.

[9] S. Dewi, E. C. Djamal, and R. Yuniarti. "Optimalisasi Penempatan Guru Sekolah Dasar di Kecamatan Cikajang Kabupaten Garut Menggunakan Algoritma Genetika”. Prosiding Seminar Nasional Komputer dan Informatika (SENASKI), pp.105-108, 2017.

[10] S. Jatmika, "Optimasi kenaikan dan pembagian kelas menggunakan algoritma genetika (studi kasus pada madrasah aliyah)."

[11] R. A. Pamuji, J. Zeniarja, and A. Salam. "Aplikasi Genetika Untuk Penjadwalan Mata Pelajaran di SMAN 3 Semarang." JOINS (Journal of Information System), vol 4, no. 1, pp. 87-97, 2019.

[12] Z, Zhou, F. Li, H. Zhu, H. Xie, J. H. Abawajy, and M. U. Chowdhury. "An improved genetic algorithm using greedy strategy toward task scheduling optimization in cloud environments." Neural Computing and Applications, vol. 32 no, pp. 1531-1541, 2020.

[13] T. Handoyo, A. K. Rachmawati and E. Prasetyo, "Sistem Penjadwalan Mata Pelajaran di SMA Muhammadiyah 1 Kota Magelang Dengan Algoritma Genetika", Jurnal Informasi \& Pengembangan Iptek (TRANSFORMASI), vol. 11, no. 1, 2015.

[14] I. A. Soenandi, "Konsep Algoritma Genetik Biner Untuk Optimasi Perencanaan Jadwal Kegiatan Perkuliahan”, Jurnal Teknik dan Ilmu Komputer, 2013.

[15] A. Hajjah, "Penerapan Algoritma Genetika dalam Optimasi Penjadwalan Proyek." vol. 2, no. 1, pp. 5055,2020 .

[16] W. Setiyaningsih, "Sistem Pejadwalan Kuliah Meggunakan Metode Algoritma Genetika Pada Program Magister Fakultas Ekonomi Dan Bisnis", RAINSTEK: Jurnal Terapan Sains \& Teknologi, vol.1, no. 2, pp. 40-47, 2019.

[17] I. H. Sugeha, R. L. Inkiriwang, and P. A. K Pratasis. "Optimasi penjadwalan menggunakan metode algoritma genetika pada proyek rehabilitasi puskesmas minanga." Jurnal Sipil Statik, vol. 7, no. 12, 2019.

[18] R. K. Budhi, "Aplikasi Algoritma Genetik untuk Optimasi Penjadwalan Kegiatan Perkuliahan." Jurnal Transformatika, vo. 6, no. 1, pp.1-9, 2008.

[19] E. V. M. Kom, "Performance Algoritma Genetika (GA) Pada Penjadwalan Mata Pelajaran." InfoTekJar: Jurnal Nasional Informatika dan Teknologi Jaringan, vol. 1, no. 1, pp. 56-60. 2016.

[20] A. Janata and E. Haerani. "Sistem Penjadwalan Outsourcing Menggunakan Algoritma Genetika (Studi Kasus: PT. Syarikatama)." Jurnal CoreIT: Jurnal Hasil Penelitian Ilmu Komputer dan Teknologi Informasi, vol. 1, no. 1, pp. 17-24. 2015. 


\section{BIOGRAPHY OF AUTHORS}

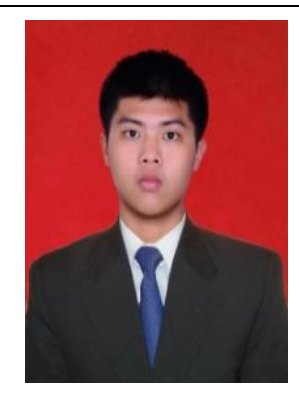

Andi he is a student in system information at faculty of computer science, Institut Bisnis dan Teknologi Pelita Indonesia. He has a passion in creating designs with two years experience in designing by Photoshop.

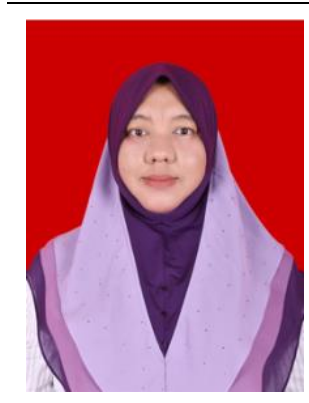

Dewi Nasien received her Ph.D. in 2012 and has worked at Universiti Teknologi Malaysia, Johor Bahru, Malaysia, from 2012 to 2016. She is currently a lecturer at a private university at Institut Bisnis dan Teknologi Pelita Indonesia. Moreover, she is also an adjunct lecturer in several universities. Her areas of expertise are in image processing, pattern recognition, machine learning, and soft computing. 